\title{
Efforts to Improve Bank Marketing Performance
}

\author{
Paulus Wardoyo ${ }^{\mathrm{a} *}$, Endang Rusdianti ${ }^{\mathrm{b}}$ \\ ${ }^{a, b}$ University of Semarang, Indonesia \\ adyalk@gmail.com
}

\begin{abstract}
This study aims to build and analyze research models that can be used to improve bank marketing performance. The population is 165 people, while the sampling technique used is purposive sampling and a sample of 135 respondents was obtained. This study uses four variables, namely satisfaction, customer retention, internet banking service quality, and marketing performance. Descriptive analysis was carried out using index numbers, completion of inferential statistics was carried out with the help of Smart software PLS version 2.0. The four hypotheses used in this study were all accepted. To improve marketing performance, management must first be able to build good relationships with its customers. Relationships must be long-term oriented and mutually beneficial.
\end{abstract}

Article Info

- Received : June 3, 2019

- Revised : August 8, 2019

- Published : September 15, 2019

- No. Pages : 268-278

- DOI : 10.33019/ijbe.v3i3.190

- JEL : G21, M31

- Keywords : index numbers, satisfaction, customer retention, internet banking

\section{Introduction}

Internet Banking is known as Online Banking or e-Banking, has provided the bank with the advantage of surviving in the face of intense competition, saving time and money, improving large-scale customization, marketing and communication activities, and for maintaining and attracting customers. Lee (2001) indicated that Internet Banking makes it easy for customers to access their bank accounts, lower service costs, and time savings. The existence of Internet Banking also influences the face of Indonesian banking. Many factors cause customers to put money in the bank. Starting from the closeness of location, satisfying service, level of security, ease of transaction facilities up to several other factors.

Internet Banking is the fastest growing service offered by banks to attract new customers (Moody, 2002). Although Internet Banking has grown rapidly, there is not enough evidence that customers have received this service well. Robinson's (2000) study states that half the customers who have tried online banking will not be active users. PT Bank Negara Indonesia (Persero) Tbk (BNI), is one of the largest banks in Indonesia and has many branches. BNI also has five service offices abroad. To improve services to customers and to meet customer needs, BNI comes with increasingly complete features. Starting from scheduled and recurring transfers. Transaction mutations for the past 6 months, open accounts, personalize your homepage, m-secure, access version mobile and various other services that can be accessed whenever and wherever you are. In 2015-2017, the use of internet banking at BNI Branch 
Offices in Kudus averaged only $27.07 \%$ of all existing account holders, so the use of internet banking by customers was still relatively low.

Research on the influence of internet banking has been carried out a lot, but research on the role of customer retention still lacks the attention of researchers. The study conducted by $\mathrm{Al}$ Hawari (2006) shows that customer retention can mediate the effect of bank automation services on the financial performance of banks, however, a study conducted by Gangeswari et al (2013) shows that customer retention directly influences company performance, besides demographic factors. which consists of age and income can moderate the effect of customer retention on company performance. Transactions that use internet banking do not affect the company's performance (Sathye, 2005; Maholtra \& Singh, 2009; Al Smadi and Al Wabel, 2011). Unlike the study conducted by Hernando and Nieto (2007); Onay et al. (2008) found that banks applying internet banking had a positive effect on bank performance. Based on the results of previous research, the research problem in this study is how the real role of customer retention and the influence of the quality of internet banking services on the bank's marketing performance While the purpose of this study is to build and test the model of the effect of customer retention and the quality of internet banking services on marketing performance.

\section{Literature Reviews}

According to Ferdinand (2000) marketing performance is an effort to measure the level of performance of the strategy produced with all expected performance on sales and finance. On the contrary, Jiminez \& Zarco (2006) stated that marketing performance needs to be seen from market attractiveness, can be measured by market size, market growth, company market position, potential sales volume, latent customer segments and the number of current competitors. Research conducted by Menon et al (1997) shows that marketing performance as an effort to measure the performance of the strategy produced by the expected level of performance, sales growth, and profit rates. Based on the results of previous studies, each researcher in measuring marketing performance has different indicators and there are several of the same. Marketing performance can be measured by sales growth and profit rates (Menon, 1997). Wilkund (1999) uses an increase in product demand and increased sales. Other research Ferdinand (2000) says marketing performance indicators are sales growth, sales growth, market share (Ferdinand, 2000; Voss \& Voss, 2000). Hsieh, Liu \& Chua (2002) concluded that establishing and maintaining relationships that bring sustainable satisfaction with services offered to users can lead to better performance.

\section{Effect of Quality Relations with Customer Retention}

Johnson (1999) mentions that in building relationships with customers, companies need to consider the quality of relationships with their buyers. This is a form of corporate responsibility expression so that the relationship can last in the long term. Relationship quality is a tool to maintain the company's competitive level and is useful for reducing transaction costs, which in turn will benefit the company (Noordewir et al, 1990; Ganesan, 1997). Thurau and Kleen (1997) state that the relationship between relationship quality and customer retention is influenced by intra psychological, contextual, and situational factors. In service marketing, future sales opportunities are very dependent on the quality of relationships (i.e., trust and satisfaction), while the ability to change these opportunities into sales depends more on the expertise of each salesperson (Crosby, Evans and Cowles, 1990). Maintaining existing customers is one of the strategic strategies to gain business profits. To retain customers, company leaders must focus on the quality role of their relationships with their customers. 
The level of customer trust is largely determined by the salesperson's experience, sales orientation, and customer orientation. Conversely, the ethical behaviour of salespeople does not influence customer trust. Therefore, financial institutions need to improve the quality of links to develop and maintain long-term relationships (Bejou; Wray and Ingram, 1996). Al Hawari (2009) in his research concluded that all conventional service quality factors carried out by retail banking positively affected customer retention. Conversely, automatic service quality generally does not have a significant positive effect on customer retention.

Ndubisi's (2007) study concluded that trust contributed more significantly $(\beta=0.476)$ to variations in the quality of the overall relationship than the other two dimensions. It was also concluded that trust is the most important predictor of relationship quality. Conflict handling $(\beta=0.259)$ ranks second in terms of contributions to variation in relationship quality, and the commitment $(\beta=0.107)$. Research conducted by Siddiqui et al (2011) proves that there is an influence of customer satisfaction and the quality of the relationship to customer retention. Furthermore, customer satisfaction and relationship quality have an important role in the banking industry, in their efforts to retain customers. Besides that, a study conducted by Tung $\&$ Carlson (2013) on the quality of relationships and their effect on retail banking, from three dimensions of relationship quality, namely: trust $(\beta=0.38)$, commitment $(\beta=0.40)$ and satisfaction $(\beta=0.33)$, indicating that the bottom dimension of satisfaction has the lowest influence among the three existing dimensions. The results of research conducted by Nataraj and Rajendran (2018) revealed that relationship quality has a significant positive impact on customer retention. Furthermore, commitment $(\beta=0.577)$ which is an antecedent of relationship quality, shows a stronger impact than the other two antecedents; that is, satisfaction $(\beta=0.259)$ and trust $(\beta=0.392)$. Therefore, the company must maintain existing customers, which is one of the bank's main strategies to gain business profits. To maintain customers, companies must focus on improving the quality of their relationships with bank customers. Based on the description above, the variable quality of relationships in this study will be proxy using the satisfaction dimension. So the hypothesis proposed in the study reads as follows;

H1: The higher the level of satisfaction, the higher the customer retention provided by banks.

\section{Effect of Customer Retention on Marketing Performance}

Customer retention related to changing the pattern of individual customer transactions, into a long-term customer relationship (Schiffman and Wisenblit, 2015); Gengeswari (2013) states that customer retention has four dimensions, namely word-of-mouth, price insensitivity, repeat purchase and non-complaining behaviour. Syaqirah et al (2014) stated that there are 3 dimensions of customer retention, namely: expectation to repurchase, recommend to others, overall satisfaction. Referring to a study conducted by Kassim (2007), which was conducted on retail banks in the United Arab Emirates, concluded that satisfaction is not the only determinant of retention in retail banking. Appiah Adu (1999) states that customer retention has a positive effect on marketing performance. The study conducted by Al Hawari (2006) shows that customer retention is able to mediate the effect of bank automation services on financial performance of banks, but the study conducted by Gengeswari et al (2013) shows that customer retention directly has an influence on company performance, other than those demographics consisting of age and income can moderate the effect of customer retention on company performance. Therefore, the hypothesis proposed in this study is:

$\mathrm{H} 2$ : The higher the quality of customer retention carried out by banks, the higher the marketing performance. 


\section{Effect of Customer Retention on the Quality of services Internet Banking}

Zangmo et al (2015) state that customer retention is an effort made by the company, to increase sales. These efforts are aimed at providing customer satisfaction by providing good quality service. Therefore, customer retention needs to be done from the start the company makes contact with customers until the company can establish business relations in the long run (Singh and Khan, 2012). Customer retention is related to changing the pattern of individual customer transactions, into long-term customer relationships (Schiffman and Wisenblit, 2015). Ennew \& Bink (1996) in the study stated that customer retention relationships have a significant effect on service quality. A study conducted by Olannye et al (2017) shows that online banking services, point of sales services and mobile banking are forms of customer retention Fast service growth using Internet Banking is a service that is widely offered by banks, as an effort to attract new customers (Moody, 2002). The results of research conducted by Hawari (2006) showed a positive influence on the quality of Bank services carried out using automation technology with customer retention rates provided by banks. Finally, a study conducted by Sohail and Shaikh (2007) showed that service quality internet banking must meet three requirements, namely: efficiency and safety, meeting needs and responsiveness. According to Singh (2014) in his research, the banking sector has developed various channels for customers for their banking needs such as ATMs, Internet Banking and telebanking. Internet Banking is based on internet usage and is mainly used in urban areas.

The study conducted by Hammoud and Bizzri (2018) found a dimension of the quality of internet banking services that is based on: showing that reliability, efficiency, and ease of use; responsive and communication; and security and privacy all have a significant impact on customer satisfaction, with reliability being the dimension with the strongest impact. EBanking has become one of the essential banking services that can, if implemented correctly, increase customer satisfaction, and give banks a competitive advantage.

H3: The higher the quality of customer retention provided by banks, the higher the quality of internet banking services.

\section{Effect of Internet Banking Quality on Marketing Performance}

A study conducted by Sathye (2005) on the effect of internet banking conducted by Credit Union in Australia shows that internet banking has not been able to become a means to improve credit performance and reduce or increase the risk of credit. The results of a study conducted by Siddik et al (2016) in Bangladesh, show that using internet banking shows that during the first two years there was a negative influence on Return on Equity, this happened, because it was the initial stage of adjustment. Furthermore, starting in the third year, the use of internet banking contributes positively to Return on Equity. Unlike the study conducted by Al Hiwari (2005), the use of internet banking mediated by customer retention improved banking performance, as well as direct use of internet banking which also affected the performance of banks. Meanwhile, the study conducted by Mahmoodi and Asetmal (2014), proved that the quality of internet banking services and customer satisfaction influenced bank performance. Besides that, customer satisfaction also has the role of mediating between internet banking and performance.

More recent study Given that banks in Kenya, Aduda (2012) show the integrity of Internet Banking to improve marketing performance. In another study, it was shown that the quality of online banking services effectively increased the satisfaction of existing customers and directly increased the performance of marketing Internet Banking. The results of research conducted by Smadi \& Wabel (2011) on the influence of internet banking in Jordan indicate a negative influence on banking performance, therefore it is recommended that the banks in conducting 
promotions to more actively emphasize trust and encourage customers to use internet banking Gutu (2014), states that the internet revolution brings benefits to all people and customers. Banks can reduce costs with labour and branches and automate their activities. Customers can reduce the time spent on banking activities and maybe some money. So that the quality of internet services has a significant impact on performance. From what has been described above, the hypothesis proposed in this study reads as follows:

H4: The higher the quality of internet banking services, the higher the marketing performance.

To get an overview of research below is presented the following research model:

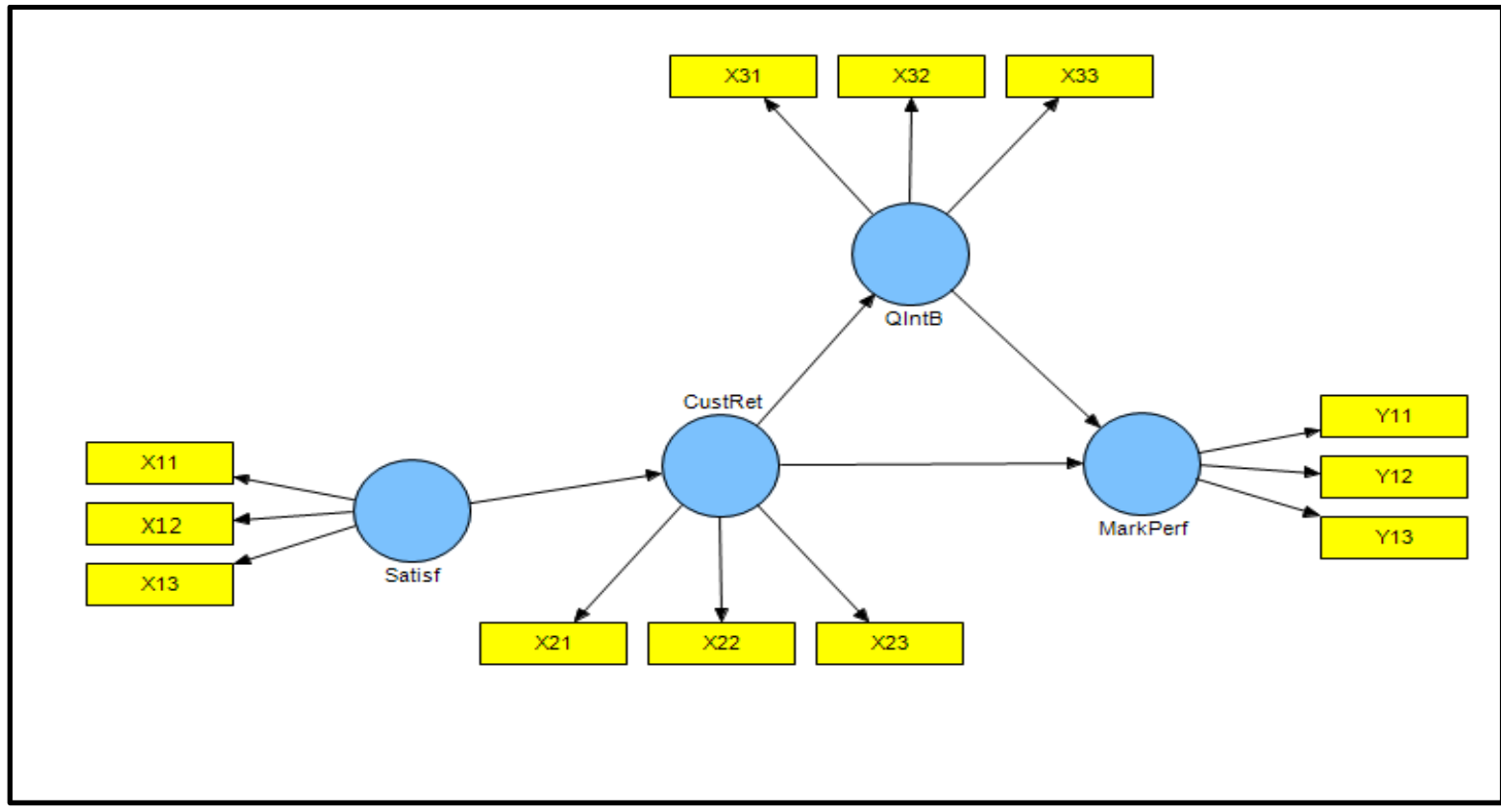

Notes:

Figure 1. Research Model

Satisf $=$ Satisfaction, Cust Ret $=$ Customer retention, QIntB $=$ Quality of Internal Banking Service, Mark Perf $=$ Marketing Performance

\section{Research Methods}

The population of this study are all marketing personnel and front liners of Bank BNI Kudus totalling 165 people. The sampling technique was carried out using purposive sampling, with criteria: Bank BNI employees in Kudus branch, work experience at BNI was more than 1 (one year), position at Bank BNI as a front liner, marketing and supervisor. Data is collected using questionnaires equipped with closed and open questions. For closed questions carried out using a Likert scale with 7 alternative answers. Descriptive statistics used frequency distribution techniques and perception index numbers. The scale of the answers is $1-10$, and the formula index number calculation formula is:

$A I=\frac{\sum_{t=1}^{7}(\% F 1 x S 1)}{7}$,

where $\mathrm{AI}=$ Index Number, $\% \mathrm{~F}_{1}=\%$ frequency of respondents in choosing the scale of the answer, and $\mathrm{S}_{1}=$ the scale of the second answer chosen by the respondent and $\mathrm{i}$ is the alternative respondent's answer between 1 and 7. 
The measurement scale starts from 1 (strongly disagree) to 7 (strongly agree). Satisfaction variable (a proxy for the quality of relationships) is measured using three indicators: wise choice, overall satisfactory, correct decision; variable customer retention is measured using three indicators: always saying positive things, always making first choice, always recommending (Hawari, 2006 \& 2009), internet banking quality measured by three indicators: according to customer needs, user friendly, safe to use (Amin, 2005 and Hawari, 2006). and marketing performance is also measured by using three indicators: market share increases, profit level increases, performance trends increase (Wijetunge, 2016). According to Ferdinand (2006), the ideal sample size for SEM is between 100-200 samples, so the minimum sample size is 5-10 observations for each indicator. Thus if the indicator estimation is 12 , then the number of minimal samples is set at 120 . This study uses a purposive sampling technique. The questionnaires distributed to respondents amounted to 150 questionnaires, the response rate was $90 \%$ or 135 respondents. The analysis was carried out using a structural equation model, completion was carried out with the help of Smart PLS software version 2.0.

\section{Results}

\section{Reliability, Validity and Structural Models}

To measure the accuracy of measuring instruments, and to find out the ability to perform its functions, in this study validity tests will be conducted. This validity test is done by looking at the results of the outer loading that appears as follows:

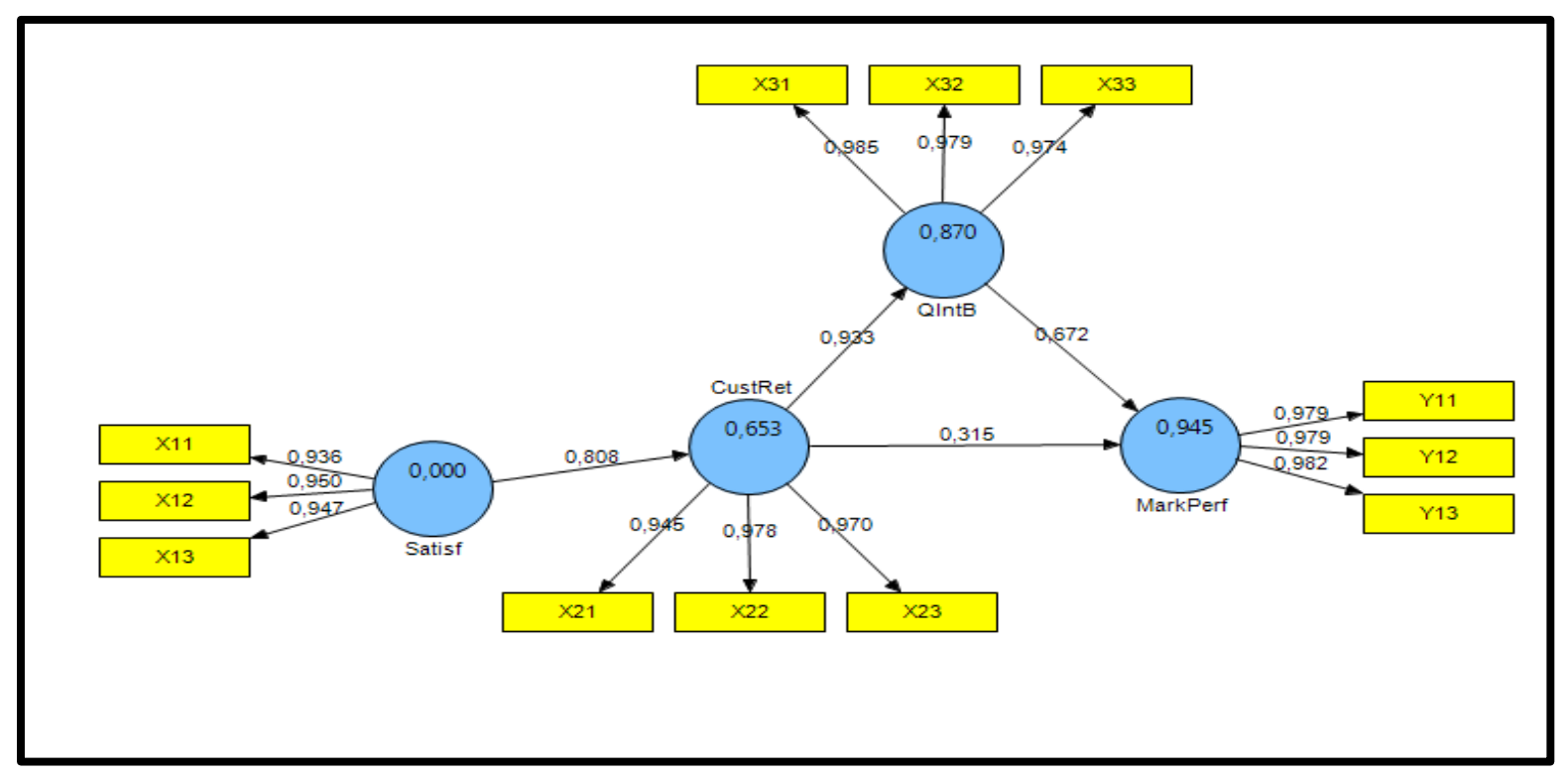

Figure 2. Loading Factor Value

From the picture above, it can be seen that the loading factor values are all above 0.6, this indicates that all indicators are valid. Besides being seen from the factor of loading convergent validity, it can be seen also the value of Average Variance Extracted (AVE). The test results appear as follows: 
Table 1. AVE Values, Composite Reliability \& Cronbach's Alpha

\begin{tabular}{|c|c|c|c|c|}
\hline & AVE & $\begin{array}{c}\text { Composite } \\
\text { Reliability }\end{array}$ & R Square & $\begin{array}{c}\text { Cronbachs } \\
\text { Alpha }\end{array}$ \\
\hline CustRet & 0,930575 & 0,97573 & 0,652973 & 0,962617 \\
\hline MarkPerf & 0,960436 & 0,986455 & 0,944892 & 0,979402 \\
\hline QIntB & 0,959176 & 0,986011 & 0,870137 & 0,978711 \\
\hline Satisf & 0,892336 & 0,961335 & & 0,93966 \\
\hline
\end{tabular}

Based on the table above, it can be seen that the AVE value of all variables has a value above 0.7 as well as the search value of Cronbach's Alpha which is all above 0,6 . Therefore, both in terms of validity and reliability, all indicators can be accepted. Next to test the structural model is done by using the value of $\mathrm{R}$ Square on the construct used in this study. From table 1 above, it can be seen that the constructed value of customer retention of $65.29 \%$ can be explained by the role of Satisfaction. While the value of R Square from the construct of Quality of Internet Banking Service by $87 \%$ can be explained from the role of customer retention. Then the value of R Square from the construct of Marketing Performance as much as $98.6 \%$ can be explained by the role of customer retention and Quality of Internet Banking Services.

\section{Hypothesis Test Hypothesis}

Testing is done using the t-test, which is the result of testing from bootstrapping, completely presented in the following table:

Table 2. Path Coefficient Model

\begin{tabular}{|c|c|c|c|c|c|}
\hline & $\begin{array}{c}\text { Original Sample } \\
(\mathrm{O})\end{array}$ & $\begin{array}{c}\text { Sample Mean } \\
(\mathrm{M})\end{array}$ & $\begin{array}{c}\text { Standard Deviation } \\
(\mathrm{STDEV})\end{array}$ & $\begin{array}{c}\text { Standard Error } \\
(\text { STERR })\end{array}$ & $\begin{array}{c}\text { T Statistics } \\
(\text { O/STERR })\end{array}$ \\
\hline CustRet -> MarkPerf & 0,314502 & 0,313514 & 0,067052 & 0,067052 & 4,69043 \\
\hline CustRet - $>$ QIntB & 0,932811 & 0,92995 & 0,020375 & 0,020375 & 45,781581 \\
\hline QIntB -> MarkPerf & 0,672055 & 0,672411 & 0,065664 & 0,065664 & 10,234705 \\
\hline Satisf -> CustRet & 0,808067 & 0,806198 & 0,072506 & 0,072506 & 11,144891 \\
\hline
\end{tabular}

The column t statistic for each construct shows that all loading factors used in this study are significant at alpha 0.05 .

\section{Path Test}

To find out how much influence the Satisfaction and the role of customer Retention and Internet Banking Service Quality on Marketing Performance will be compared to the value of the two existing lines as follows;

a. Path of Satisfaction, Customer Retention and Marketing Performance $(0.808 \times 0.314=$ 0.256)

b. Path of Satisfaction, Customer Retention, Internet Banking Service Quality and Marketing Performance $(0.808 \times 0.932 \times 0.672=0.506)$

Calculation results show that the second path has a higher value, by increasing marketing performance, the role of satisfaction, customer retention and the quality of internet banking services are important. 


\section{Discussion \\ Effect of Satisfaction on Customer Retention}

The results of this study indicate that the three indicators used to measure satisfaction each have the following loading factors: a wise choice (0.936), the correct decision (0.960) and overall satisfactory $(0.947)$. Of the three indicators, the correct decision indicator has the highest loading factor. The quality of the proxy relationship using satisfaction turns out to influence customer retention. The average index number of satisfaction variables is 74.97 in the high category. The results of this study have corresponds to the study conducted by Siddiqui et al (2011), Tung \& Carlson (2013) and Nataraj \& Rajendran (2018).

\section{Effect of Customer Retention on Marketing Performance.}

Customer retention is formed by three indicators, where the loading factor value of each indicator is: always say positive things $(0.946)$, be the first choice $(0.978)$ and want to recommend (0.970). The highest value of the loading factor is in the second indicator, which is the first choice. The results of the calculation of the average index number for the customer retention variable is 76.52 , which means it is in the high category. The results showed that customer retention influenced marketing performance. This result is following the study conducted by Appiah Adu (1999), Hawari (2006) and Gangeswari et al (2013).

\section{Effect of Customer Retention on Internet Banking Service Quality}

From the results of the data, the quality of internet banking is measured by three indicators of each loading factor that is according to customer needs (0.985), user-friendly (0.979), safe to use (0.974). The study proves that customer retention influences the quality of internet banking services. The higher the customer's rent is done by the Bank, the higher the quality of internet banking services. The quality of good internet banking services needs to be done by providing various features needed by customers, such as balance checks, transfers, account transfers, telephone calls or electricity bills, etc. Besides, the quality of internet banking services must be accessible from various places, by using a variety of computers, laptops, smartphones or tablets, the Bank as an internet banking service provider needs to provide security guarantees for customers in conducting transactions. The results of this study are in accordance with the study conducted by Venetis and Ghauri (2004), Sohail and Shaikh (2007), Singh (2014). The calculation results of the average index number are 80.37 in the high category.

\section{Effect of Internet Banking Service Quality on Marketing Performance}

The results of the study show that marketing performance variables are measured using three indicators, the value of each loading factor is as follows: an increase in market share (0.979), an increase in profitability (0.979) and performance trends which increases (0.982). Increased performance trend indicators have the highest loading factor. The results of the statistical tests show that the quality of internet banking services can influence marketing performance. Two variables directly affect marketing performance, namely customer retention and the quality of internet banking services. However, the influence of the quality of internet banking services on marketing performance has a stronger influence than the effect of customer retention. The results of this study support the research conducted by Siddik et al (2016), Hiwari (2005), Mahmoodi and Asetmal (2014) and Aduda (2012). Meanwhile, the calculation of the average index of marketing performance variables is 81.15 which falls into the category high.

\section{Conclusion and Suggestion}

Referring to the research results, it can be concluded that high marketing performance is strongly influenced by the quality of mutually satisfying relationships between the two parties, 
in addition to the implementation of customer retention and support for the quality of internet banking services. To improve marketing performance, management must first be able to build good relationships with its customers. Relationships must be long-term oriented and mutually beneficial. One of these good relationships needs to be realized through the provision of banking services that can be accessed through the internet for 24 hours, easy to use and guaranteed to be safe. It is highly recommended, for the upcoming agenda, research can be carried out with a wider range of areas, mass in the banking industry nationally, and adding other necessary variables.

\section{Acknowledgement}

The author would like to thank you. Diah Noor Ekawati, an employee of Bank BNI Kudus, who has been pleased to be an enumerator in this research.

\section{References}

1) Aduda, J., \& Kingoo, N. (2012). The Relationship between Electronic Banking and Financial Performance among Commercial Banks in Kenya. Finance, 1(3), 99-118.

2) Al-Hawari, M. (2007). The effect of automated service quality on bank financial performance and the mediating role of customer retention. Journal of Financial Services Marketing, 10(3), 228-243. https://doi.org/10.1057/palgrave.fsm.4770189

3) Al-Hawari, M., Ward, T., \& Newby, L. (2009). The relationship between service quality and retention within the automated and traditional contexts of retail banking. Journal of Service Management, 20(4), 455-472. https://doi.org/10.1108/09564230910978539

4) Al-Smadi, M. O., \& Al-Wabel, S. A. (2011). The Impact of E-Banking on The Performance of Jordanian Banks. Journal of Internet Banking and Commerce, 16(02). Retrieved from http://www.arraydev.com/commerce/jibc

5) Amin, Muslim. (2016), Internet Banking Service Quality and It's Implication on e-Customer Satisfaction and e-Customer Loyalty, International Journal of Bank Marketing, Vol.34.Iss3, pp.280-306.

6) Appiah Adu, Kwaku. (1999), Marketing Effectiveness and Customer Retention in the Service Sector, The Service Industries Journal, Vo 19, Issue 3, pp 26-41.

7) Bejou, D., Wray, B., \& Ingram, T. N. (1996). Determinants of relationship quality: An artificial neural network analysis. Journal of Business Research, 36(2), 137-143. https://doi.org/10.1016/0148-2963(95)00100-X.

8) Crosby, L. A., Evans, K. R., \& Cowles, D. (1990). Relationship Quality in Services Selling: An Interpersonal Influence Perspective. Journal of Marketing, 54(3), 68-81. Retrieved from http://www.jstor.org/page/info/about/policies/terms.jsp.

9) Ennew, C. \& Binks, M (1996). The Impact of Service Quality and Service Characteristics on Customer Retention: Small Business and their Banks in the UK. British Journal of Management, 7, 219-230.

10) Ferdinand, A. T, (2000). Marketing Management: A Strategic Approach, Research Paper Series Marketing Management Concentration, Diponegoro University Publishing Agency, Semarang.

11) Ganesan, S. (2015). Determinants of long-term in buyer-seller orientation relationships. Journal of Marketing, 58(2), 1-19.

12) Gengeswari, K., Padmashantini, P., \& Sharmeela-Banu, S. (2013). Impact of Customer Retention Practices on Firm Performance. International Journal of Academic Research in Business and Social Sciences, 3(7), 68-84. https://doi.org/10.6007/ijarbss/v3-i7/10.

13) Gounaris, S. P., \& Venetis, K. (2002). Trust in industrial service relationships: Behavioral consequences, antecedents and the moderating effect of the duration of the relationship. Journal of Services Marketing, 16(7), 636-655. https://doi.org /10.1108/0887 6040210447351

14) Gutu, L. M. (2014). The impact of internet technology on the Romanian bank's performance. 12th International Academic Conference, (September), 495-501. 
15) Hammoud, J., Bizri, R. M., \& El Baba, I. (2018). The Impact of E-Banking Service Quality on Customer Satisfaction: Evidence from the Lebanese Banking Sector. SAGE Open, 8(3). https://doi.org/10.1177/2158244018790633

16) Hennig-Thurau, T., \& Klee, A. (1997). The impact of customer satisfaction and relationship quality on customer retention: A critical reassessment and model development., Der Einfluss von Kundenzufriedenheit und Beziehungsqualitaet auf Kundentreue: Eine kritische Neubewertung und Entwicklung e. Psychology \& Marketing, 14(8), 737-764. Retrieved from http://ovidsp.ovid.com/ovidweb.cgi?T=JS\&PAGE=reference $\& D=$ psyn\&NEWS $=\mathrm{N} \& A N=0126638$

17) Hernando, I., \& Nieto, M. J. (2007). Is the Internet delivery channel changing banks' performance? The case of Spanish banks. Journal of Banking and Finance, 31(4), 1083-1099. https://doi.org/10.1016/j.jbankfin.2006.10.011

18) Hsieh, Y. C., Lin, N. P., \& Chiu, H. C. (2002). Virtual factory and relationship marketing - A case study of a Taiwan semiconductor manufacturing company. International Journal of Information Management, 22(2), 109-126. https://doi.org/10.1016/S0268-4012(01)00049-4

19) Jiménez-Zarco, A. I. (2006). Performance Measurement System Integration into New Product Innovation. 2006(9).

20) Johnson, J. L. (1999). Strategic integration in industrial distribution channels: Managing the interfirm relationship as a strategic asset. Journal of the Academy of Marketing Science, 27(1), 418. https://doi.org/10.1177/0092070399271001

21) Lee, Chung-Shing (2001). An analytical framework for evaluating e-commerce business models and strategies. Internet Research, 11(4), 349-359. https://doi.org/10.1108/10662240110402803

22) Malhotra, P., \& SINGH, B. (2009). No Title. Eurasian Journal of Business and Economics, 2(4), 43-62.

23) Mohmoodi, A. P., \& Asetmal, A. K. (2014). Surveying the Impact Quality of the Bank's electronic Services on Financial Performance (with the Emphasis on the Customer Satisfaction Model). European Journal of Sustainable Development, 3(2), 97-108. https://doi.org/10.14207/ejsd.2014.v3n2p97

24) Menon, A., \& Menon, A. (2006). Entrepreneurial Marketing Strategy: The Emergence of Corporate Environmentalism as Market Strategy. Journal of Marketing, 61(1), 51. https://doi.org/10.2307/1252189

25) Moody, J. (2002), "Traditional banks gain edge with electronic banking", available at www.cendant.com/media/trends_information/trends_information.cgi/MarketingpServices/59 (accessed May 20, 2019)

26) Nataraj, B. (n.d.). Impact of Relationship Quality on Customer Retention - A Study with Reference to Retail Banking in India. International Journal of Business and Information, 13(1), 93-118. https://doi.org/10.6702/ijbi.201803

27) Ndubisi, N. O. (2007). Relationship quality antecedents: The Malaysian retail banking perspective. International Journal of Quality and Reliability Management, 24(8), 829-845. https://doi.org/10.1108/02656710710817117

28) Nisha Bani Siddiqui, Sangeeta Jain, Shine David, Kanhaiya Sharma, S. P. (2011). the Impact of Customer Satisfaction and Customer Relationship Quality on Customer Retention: With Special Reference to Banking Industry. In Review of Business and Technology Research.

29) Noordewier, T. G., John, G., \& Nevin, J. R. (2006). Performance Outcomes of Purchasing Arrangements in Industrial Buyer-Vendor Relationships. Journal of Marketing, 54(4), 80. https://doi.org/10.2307/1251761

30) Olannye, A. P., Dedekuma, S. E., \& Ndugbe, E. H. (2017). Enhancing Customer Retention through Electronic Service Delivery Channels in the Nigerian Banking Industry. International Journal of Business Administration, 8(5), 57. https://doi.org/10.5430/ijba.v8n5p57

31) Sadiq Sohail, M., \& Shaikh, N. M. (2008). Internet banking and quality of service. Online Information Review, 32(1), 58-72. https://doi.org/10.1108/14684520810865985

32) Sathye, M. (2008). The impact of internet banking on performance and risk profile: Evidence from Australian credit unions. Journal of Banking Regulation, 6(2), 163-174. https://doi.org/10.1057/palgrave.jbr.2340189 
IJBE: Integrated Journal of Business and Economics e-ISSN: 2549-3280

33) Siddik, M. N. A., Sun, G., Kabira, S., Shanmugan, J., \& Yanjuan, C. (2016). Impacts of E-Banking on Performance of Banks in a Developing Economy: Empirical Evidence from Bangladesh. Journal of Business Economics and Management, 17(6), 1066-1080. https://doi.org/10.3846/16111699.2015.1068219

34) Singh, R., \& Khan, I. A. (2012). An Approach to Increase Customer Retention and Loyalty in B2C World. International Journal of Scientific and Research Publications, 2(6), 1-5. Retrieved from http://www.ijsrp.org/research_paper_jun2012/ijsrp-June-2012-40.pdf

35) Singh, Shamser. (2014). Customer-perceived Internet Banking Service Quality: A Measurement and Nomological Validity, Journal of Marketing Research, VI.XXVII.pp.61-69

36) Syaqirah, Z. N., \& Faizurrahman, Z. P. (2014). Managing Customer Retention of Hotel Industry in Malaysia. Procedia - Social and Behavioral Sciences, 130, 379-389. https://doi.org/10.1016/j.sbspro.2014.04.045

37) Tung, B., \& Carlson, J. (2013). Modelling a Formative Measure of Relationship Quality and Its Effects: Evidence from the Hong Kong Retail Banking Industry. Services Marketing Quarterly, 34(2), 139-158. https://doi.org/10.1080/15332969.2013.770674

38) Voss, G. B., \& Voss, Z. G. (2000). Strategic Orientation and Firm Performance in an Artistic Environment. Journal of Marketing, 64(1), 67-83. https://doi.org/10.1509/jmkg.64.1.67.17993

39) Wijetunge, W. A. D. (2016). Service Quality, Competitive Advantage and Business Performance in Service Providing SMEs in Sri Lanka. International Journal of Scientific and Research Publications, 6(7), 720-728.

40) Zangmo, M., Liampreecha, W., \& Chemsripong, S. (2015). the Influencing Factors of Customer Retention in Airline Industry: A Case of Drukair Royal. Asia Business and Economics Journal, 8492. 